\title{
Intussuscepção jejuno-jejunal em potro
}

Victória Camara Antunes', Rafael Ricci Mota, Raphael Henrique Alvares, Rodrigo Rolim Duarte

*Autor correspondente

e-mail: viiantunes@live.com

\section{Resumo}

A intussuscepção ocorre quando um segmento de alça intestinal se invagina em outro segmento. Sua severidade está diretamente relacionada à obstrução, parcial ou completa, do lúmen intestinal e do suprimento sanguíneo. Nos equinos, os animais jovens são mais acometidos, tendo maior casuística em potros de duas a cinco semanas de vida. Os fatores predisponentes desta enfermidade estão relacionados a alterações que causam hipermotilidade como infestação por vermes redondos ou achatados, mudança na dieta, alimentos grosseiros e mal digeridos, diarreias, enterites, neoplasias intraluminais, entre outros. Animais acometidos apresentam dores abdominais contínuas de intensidade moderada à severa, perda de peso, depressão, febre intermitente, mucosas congestas e fezes escassas. Um equino, macho, da raça quarto de Milha, com três meses de idade e pesando aproximadamente $120 \mathrm{~kg}$, foi encaminhado ao hospital veterinário do Centro Universitário de Maringá, Unicesumar. 0 histórico era de dor abdominal intensa não responsiva à terapia analgésica e com evolução de aproximadamente dez horas. Durante o exame clínico, constatou-se aumento da frequência cardíaca $(110 \mathrm{bpm})$, frequência respiratória de $24 \mathrm{mpm}$, desidratação moderada, mucosas congestas, hipertermia $\left(38,9^{\circ} \mathrm{C}\right)$ e ausência da motilidade do trato gastrointestinal. A paracentese abdominal foi improdutiva. Com base na avaliação clínica, o animal foi imediatamente encaminhado para o centro cirúrgico sendo submetido à laparotomia exploratória, que revelou quadro de intussuscepção jejunojejunal. Foi realizada a ressecção da porção acometida e feita a anastomose do jejuno. A avaliação pósenterectomia do intussuscepto revelou avançado grau de congestão, extensa área de necrose e infestação por Strongylus vulgaris. A forma mais comum de intussuscepção em equinos é a íleo-cecal, porém outros segmentos de alça intestinal podem ser acometidos como, por exemplo, a intussuscepção ceco-cólica, cecocecal, jejuno-jejunal. Esta enfermidade apresenta níveis de gravidade variáveis, diretamente relacionada com o tamanho do segmento envolvido bem como a magnitude do comprometimento circulatório, sendo na 
maioria das vezes considerados casos graves. A palpação transretal, radiografia e a ultrassonografia podem auxiliar no diagnóstico das intussuscepções, porém na maioria dos casos é a laparotomia exploratória que confirma o diagnóstico. 0 prognóstico da intussuscepção é reservado. A severidade do caso é proporcional ao tempo de evolução e grau do comprometimento vascular, visto que quadros de peritonite decorrentes da migração bacteriana pela parede intestinal comprometida, juntamente com o desenvolvimento de processos toxêmicos desencadeados pela necrose intestinal, são frequentes. Frente ao exposto, acredita-se que o pronto encaminhamento ao centro cirúrgico é fator fundamental e determinante para o sucesso do tratamento da intussuscepção.

Palavras-chave: Intussuscepção. Jejuno. Verminose. 